\title{
Juvenile growth in barnacles: combined effect of delayed metamorphosis and sub-lethal exposure of cyprids to low-salinity stress
}

\author{
V. Thiyagarajan ${ }^{1}$, J. A. Pechenik ${ }^{2}$, L. A. Gosselin ${ }^{3}$, P. Y. Qian ${ }^{1, *}$ \\ ${ }^{1}$ Department of Biology/Coastal Marine Laboratory, The Hong Kong University of Science and Technology, Kowloon, \\ Hong Kong SAR \\ ${ }^{2}$ Department of Biology, Tufts University, Medford, Massachusetts 02155, USA \\ ${ }^{3}$ Department of Biological Sciences, Thompson Rivers University, Kamloops, British Columbia V2C 5N3, Canada
}

\begin{abstract}
Delayed metamorphosis can affect post-metamorphic performance in a variety of marine invertebrate species, possibly through effects on larval energy reserves. Nevertheless, the consequences of the 'latent effects' of natural environmental conditions and the proximate causes of the effects have rarely been examined. We documented the combined effect of delayed metamorphosis and sub-lethal exposure of larvae to low-salinity stress on depletion of energy reserves, metamorphic success and juvenile growth rates for the estuarine barnacle Balanus amphitrite, both in the laboratory and in field outplant experiments. Acute $(24 \mathrm{~h})$ exposure of $0 \mathrm{~d}$ old cyprids to low salinity (10 psu) dramatically reduced juvenile growth rates (measured as basal diameter, dry weight and ash-free dry weight) for the first $5 \mathrm{~d}$ after metamorphosis, in both laboratory and field conditions, and the effects were similar to those resulting from delayed metamorphosis. There was an interaction between delayed metamorphosis and salinity effects on juvenile tissue growth rates. To determine how the negative effects of delayed metamorphosis observed in the laboratory might be modulated in the field under different nutrient conditions, we also outplanted juveniles from cyprids that had delayed metamorphosis for either $0 \mathrm{~d}$ (control) or $4 \mathrm{~d}$ at 2 intertidal sites that experienced different nutrient conditions. Surprisingly, surplus food availability in the juvenile habitat could not entirely compensate for the negative effects imposed by delayed metamorphosis on juvenile growth rates. Additionally, we examined whether or not the detrimental effects of delayed metamorphosis on growth were mediated through effects on juvenile feeding rates and feeding appendage (cirri) morphology. Interestingly, although 2 out of the 3 juvenile feeding cirri lengths were shorter than expected in delayed individuals, mean juvenile filtration rate was significantly higher in delayed individuals than in control individuals. Overall, our results emphasise that acute exposure of competent larvae to low-salinity stress negatively affects juvenile growth rates as severely as delayed metamorphosis, which may ultimately influence juvenile and adult population dynamics in the field. The cause of reduced post-metamorphic performance in young barnacles remains unclear, but does not seem to be caused by reduced capacity for feeding.
\end{abstract}

KEY WORDS: Barnacle $\cdot$ Balanus amphitrite $\cdot$ Juvenile growth $\cdot$ Delayed metamorphosis $\cdot$ Lowsalinity stress $\cdot$ Latent effects

\section{INTRODUCTION}

For marine invertebrates with complex life cycles, such as barnacles, pre- and post-metamorphic factors operating at a variety of spatial and temporal scales determine the successful addition of recruits to a population (e.g. Raimondi 1990, Miron et al. 1999, Olivier et al. 2000, Underwood \& Keough 2001). Prior to metamorphosis, planktotrophic nauplii of barnacles metamorphose into non-feeding cyprids. In the presence of 
suitable substratum and environmental stimuli, these cyprids then attach and metamorphose into sessile juveniles. Following successful metamorphosis, rapid juvenile growth is likely to be a particularly important determinant of future success, as post-recruitment mortality is often greatest in the first few days after metamorphosis, while juveniles are small and their shells are still thin (e.g. Gosselin \& Qian 1996, Thiyagarajan et al. 2005). Thus, any factors that reduce rates of juvenile growth and survival are likely to affect recruitment success (e.g. Larsson \& Jonsson 2006).

Juvenile barnacles rely on energy reserves at metamorphosis for growth and survival until the development of their digestive system is completed (Rainbow \& Walker 1977, Anderson 1994). One factor that influences both cyprid energy reserves at metamorphosis and post-metamorphic growth rates is delayed metamorphosis. The ability to postpone metamorphosis once larvae have become competent has been considered as a selective advantage because it enhances the probability of locating a favourable habitat for postmetamorphic growth (reviewed by Pechenik 1999). Such potential benefits, however, come at a cost to subsequent juvenile performance. For instance, delaying metamorphosis for only $3 \mathrm{~d}$ in the laboratory dramatically reduced post-metamorphic growth rates in barnacles (Thiyagarajan et al. 2003a).

The specific mechanisms by which delayed metamorphosis produces detrimental latent effects on juvenile performance have not yet been elucidated (Pechenik 2006). One proposed mechanism is that delaying metamorphosis reduces energy reserves at the time of metamorphosis, and that these low energy reserves would in turn only support low growth and survival in the early juvenile stage (e.g. Pechenik et al. 1993, Miller \& Emlet 1999, Thiyagarajan et al. 2003a). If this hypothesis is correct, then any larva delaying metamorphosis that also experiences an environmental stress requiring increased energy expenditure, such as the osmotic shock of low salinity (Anger 2003), might be subjected to cumulative detrimental effects on juvenile performance.

The primary goal of the present study was to explore the consequences of delayed metamorphosis and acute exposure of cyprid larvae to low-salinity stress on postmetamorphic growth rates in the estuarine barnacle Balanus amphitrite. We also attempted to understand the mechanisms by which larval experience affects post-metamorphic fitness. This was achieved by (1) examining the combined effects of delayed metamorphosis and sub-lethal exposure of larvae to lowsalinity stress on cyprid energy reserves, on metamorphic success and on juvenile growth, using both laboratory and field outplant experiments; (2) determining whether the negative effects of delayed meta- morphosis on juvenile performance might be moderated by increased food availability to the early juvenile; and (3) determining whether delaying metamorphosis reduces juvenile growth rates by reducing the ability of the early juvenile to collect food particles from the surrounding seawater, for example, by altering the morphology of the food-collecting appendages (cirri).

\section{MATERIALS AND METHODS}

General methods. Larval rearing: Adult Balanus amphitrite Darwin used as broodstock for the experiments in this study were collected from pilings in Port Shelter, Hong Kong $\left(22^{\circ} 19^{\prime} \mathrm{N}, 114^{\circ} 16^{\prime} \mathrm{E}\right)$. Nauplius larvae were obtained from several (50 to 200) adults and reared to the cyprid stage at a density of 2 nauplii $\mathrm{ml}^{-1}$ in $0.22 \mu \mathrm{m}$ filtered seawater (FSW) at $28^{\circ} \mathrm{C}$, using the diatom Chaetoceros gracilis as food according to Thiyagarajan et al. (2003b). Under these culture conditions most of the nauplii metamorphosed to the cyprid stage within $4 \mathrm{~d}$.

Cyprid lipid content: Cyprid energy reserves were quantified by measuring total lipid content. Lipids were quantified by sulphuric acid charring (Marsh \& Weinstein 1966), with tripalmitin as a standard. Three replicates, each consisting of 50 cyprids, were analysed for each measurement.

Cyprid metamorphosis: Cyprids were allowed to attach and metamorphose onto polystyrene Petri dishes (Falcon No. 1006) in full strength FSW (34 psu). Dishes were incubated at $28^{\circ} \mathrm{C}$ for $24 \mathrm{~h}$, after which percentage metamorphosis was recorded according to Rittschof et al. (1992). Six replicate dishes were used for each treatment, with 20 to 25 cyprids replicate ${ }^{-1}$. Metamorphosed cyprids were then used for subsequent examination of juvenile growth.

Juvenile growth: The procedure for monitoring juvenile growth was adopted from Pechenik et al. (1993). Juvenile basal diameter (rostro-carinal), as well as dry and ash-free dry weight (DW and AFDW, respectively), of juveniles aged $5 \mathrm{~d}$ post-metamorphosis were used to assess juvenile growth. In each experiment, the basal diameter of juveniles was determined using the ocular micrometer of a dissecting microscope (Olympus SZX12) at 100×, to an accuracy of $0.001 \mathrm{~mm}$. The juveniles (generally 10 to $15 \mathrm{pan}^{-1}$ ) were then carefully removed from their dishes, rinsed briefly with distilled water to remove adhering salts, and grouped in pre-weighed foil pans to measure the DW and AFDW. Pans containing the specimens were dried at $75^{\circ} \mathrm{C}$ for $48 \mathrm{~h}$ and subsequently weighed to the nearest $0.001 \mathrm{mg}$. The pans were then placed in a muffle furnace at $525^{\circ} \mathrm{C}$ for $8 \mathrm{~h}$ and then reweighed. The AFDW 
was calculated by dividing the total weight lost during combustion by the number of juveniles in the pan.

Expt 1-effects of delayed metamorphosis and low-salinity stress on cyprids and juveniles: a laboratory study. This entire experiment, described below, was repeated 3 times, each time using cyprids obtained from a different larval spawning events (Batches 1 to 3) from June to August 2004. Cyprids originating from a single laboratory spawning event, reared together as nauplii, and having all moulted from nauplii to cyprids within a $4 \mathrm{~d}$ period were haphazardly divided into 7 groups ( 500 ind. group ${ }^{-1}$ ). Larvae in Group 1 were used as a control (no delay in metamorphosis and no salinity stress). Cyprids in Group 1 were subdivided into 2 subgroups; larvae in one subgroup were used to quantify initial energy reserves ( $0 \mathrm{~d}$ old cyprids), and larvae in the other subgroup were placed in Petri dishes with FSW to determine percent metamorphosis and subsequent juvenile growth rates (measured as basal diameter, DW and AFDW 5 d post-metamorphosis). Cyprids in Groups 2, 3 and 4 were maintained for $24 \mathrm{~h}$ at 10, 15 and 34 psu FSW, respectively, in Teflon-coated containers. Cyprids in each of these 3 groups were then haphazardly divided into 2 subgroups, one subgroup being used for energy reserve analysis and the other subgroup of larvae being placed in Petri dishes to quantify rates of cyprid metamorphosis and juvenile growth. Cyprids in Groups 2, 3 and 4 were therefore exposed to different salinity treatments for $1 \mathrm{~d}$, and thus also a delayed attachment of $1 \mathrm{~d}$, before being allowed to metamorphose. Cyprids exposed to $34 \mathrm{psu}$ (Group 4 cyprids) served as salinity treatment controls, experiencing a $1 \mathrm{~d}$ delay of metamorphosis, but no salinity stress. Cyprids in Groups 5, 6 and 7 were forced to delay metamorphosis for $3 \mathrm{~d}$ at full salinity (34 psu) and $28^{\circ} \mathrm{C}$ by transferring them to Tefloncoated dishes; the low surface energy of Teflon dishes prevents cyprid antennules from making permanent contact with the surface, thus preventing metamorphosis (Pechenik et al. 1993). After $3 \mathrm{~d}$ at full salinity, cyprids in Groups 5, 6 and 7 were then transferred to Teflon-coated containers with seawater of 10,15 and $34 \mathrm{psu}$, respectively, for $24 \mathrm{~h}$. The following day, the cyprids in each group were subdivided for analysis of energy reserves as well as percent metamorphosis and juvenile growth rate. Thus, cyprids in Groups 5, 6 , and 7 experienced a 3 d delay of metamorphosis in full-salinity seawater plus an additional day of delayed metamorphosis in their respective salinity treatment (we refer to these as $4 \mathrm{~d}$ old cyprids).

To determine the growth of juveniles obtained from the above 7 groups of cyprids, newly metamorphosed juveniles were reared under controlled laboratory conditions with excess food for $5 \mathrm{~d}$. Dishes with juveniles were attached to $30 \mathrm{~cm}$ long glass rods (5 dishes $\operatorname{rod}^{-1}$ and 10 to 25 juveniles dish ${ }^{-1}$ ), which were then suspended vertically in a 251 plastic aquarium. All the juveniles within each experiment were therefore reared within the same body of water. Water was not changed during the $5 \mathrm{~d}$ of the experiment, but phytoplankton (3:1 mixture of Chaetoceros gracilis and Isochrysis galbana cells) was added daily at a concentration of about $10^{5}$ cells $\mathrm{ml}^{-1}$ (algal cell density was estimated using a haemocytometer) as food for the juveniles. Juveniles that survived to the end of the experiment were used for DW and AFDW measurements. Only individuals that did not experience crowding during growth were included in the analysis. Irrespective of cyprid treatments, $>75 \%$ of juveniles survived to the end of the experiment; therefore, mortality data are not shown in the present study.

Data were tested for homoscedasticity using Cochran's test and for the normality assumption using the Komogorov-Smirnov test. The square-root-transformed data for cyprid energy reserves, basal diameter, DW and AFDW were first analysed by 2-way ANOVA. Data on percentage cyprid metamorphosis were arcsine transformed and then used in ANOVA. Due to a strong interaction between factors (delayed metamorphosis and salinity), the effect of each factor was tested at a fixed level of the other factor using 1-way ANOVA (data not shown) and Tukey's multiple comparison test. In addition, a Dunnett test was used for comparing the treatments (i.e. results from Group 2 to 7 cyprids) with the control (i.e. results from Group 1 cyprids).

Expt 2-effects of delayed metamorphosis and lowsalinity stress on juvenile growth: a field study. This experiment quantified the combined effects of delayed metamorphosis and low-salinity stress during the cyprid stage on early juvenile performance in a natural setting. The juveniles used in this experiment were settlers from Groups 1, 2, 4, 5 and 7 in Expt 1, and had therefore experienced 1 or $4 \mathrm{~d}$ delays in metamorphosis and either the 10 or 34 psu salinity treatments as cyprids (cyprids exposed to 15 psu were not included in this experiment). To determine the growth of juveniles derived from these 5 of the 7 groups of cyprids under field conditions, dishes with early juveniles were tied to ropes, confined in a nylon mesh bag $(1400 \mu \mathrm{m})$ and placed in the intertidal zone ( $1 \mathrm{~m}$ above Chart Datum) near a pier at the University of Science and Technology (UST) in Hong Kong for $5 \mathrm{~d}$. At the end of each experiment, the basal diameter, DW and AFDW of the surviving juveniles were measured and statistically analysed as described in Expt 1. This experiment was repeated only once with cyprids obtained from the third batch of larvae in Expt 1. 
Expt 3-effect of delayed metamorphosis on juvenile growth at field sites differing in food availability. In this experiment, juveniles (whose cyprids were forced to delay metamorphosis for 0 or $4 \mathrm{~d}$ ) were outplanted from the laboratory to 2 field sites differing in food availability. To evaluate the food availability, replicate water samples were collected at each study site during the study period. Food availability at each study site was determined according to Shriver et al. (2002). Chlorophyll a (chl a) was used as a measure of the phytoplankton quantity available to juvenile barnacles, whereas the $\mathrm{C} / \mathrm{N}$ ratio was used as a measure of food quality (Sanford \& Menge 2001). Chl a concentration was determined fluorometrically (Parson et al. 1984). The total organic carbon (TOC) content and $\mathrm{C} / \mathrm{N}$ ratio were analysed by a PerkinElmer 2400 Series II CHNS/O analyser. This experiment was repeated 3 times from April to June 2006, each time using cyprids obtained from a different spawning event. The Old Airport (OA) site, located in the central region of Hong Kong $\left(22^{\circ} 17^{\prime} \mathrm{N}, 114^{\circ} 09^{\prime} \mathrm{E}\right)$, is characterised by high chl a concentrations (indicating high quantities of food for filter feeders) and a low $\mathrm{C} / \mathrm{N}$ ratio (indicating high food quality for filter feeders). In contrast, the UST site is located in the eastern oceanic side of Hong Kong $\left(22^{\circ} 19^{\prime} \mathrm{N}, 114^{\circ} 16^{\prime} \mathrm{E}\right)$ and is characterised by low chl $a$ and a high $\mathrm{C} / \mathrm{N}$ ratio (Thiyagarajan et. al. 2005). At each site, study locations with similar (for both sites) wave exposure and current speeds were chosen for the juvenile outplant experiment. Thus, these 2 sites were well suited for investigating the effect of food availability in natural habitats on the growth of juveniles whose cyprids were forced to delay metamorphosis for 0 or $4 \mathrm{~d}$. At each site, we installed 3 PVC frames $(40 \times 40 \mathrm{~cm})$, one for each of the cyprid batches. Each frame was attached with cable ties to 1 end of a rope hanging vertically from the pier; frames were attached at a height corresponding to $\sim 1 \mathrm{~m}$ above Chart Datum, and set at $10 \mathrm{~m}$ intervals along the shoreline. Each frame contained 3 replicate dishes per juvenile category ( 0 or $4 \mathrm{~d}$ delay); these dishes contained juveniles having been prepared specifically for this experiment in the same way as described for Expt 1. Each replicate dish contained 25 to 50 juveniles; thus, for each treatment there were 3 replicate dishes per frame and 3 frames per site, for a total of 9 replicates per habitat per delayed metamorphosis treatment. After $5 \mathrm{~d}$, the experiment was terminated and juvenile growth measurements (DW and AFDW) were carried out as described for Expt 1. To determine the effects of delayed metamorphosis and food availability in the juvenile habitat on juvenile growth achieved $5 \mathrm{~d}$ after metamorphosis, the square-root-transformed DW and AFDW data were analysed using a 2-factor ANOVA.
Expt 4-relationship between juvenile basal diameter and length of feeding cirri. This experiment examined whether cyprids that experience delayed metamorphosis develop into juveniles with proportionally shorter feeding appendages. This experiment was conducted from April to June 2006 using cyprids obtained from the third batch of Expt 3. Cyprids were allowed to metamorphose on either Day 0 or 4 ; the resulting juveniles were then cultured for up to $6 \mathrm{~d}$ in the laboratory on a mixed diet of Chaetoceros gracilis and Isochrysis galbana (3:1 mixture; $10^{5}$ cells $\left.\mathrm{ml}^{-1}\right)$ at $28^{\circ} \mathrm{C}$. A sub-sample of juveniles was examined on Days 2, 4 and 6. The basal diameter (rostro-carinal axis) of each individual was measured at $100 \times$ using an ocular micrometer. Each juvenile was then dissected, and the lengths of Feeding Cirri IV, V and VI were measured according to Crisp \& Maclean (1990). Briefly, the cirri were dissected out, videotaped and measured at the same magnification $(100 \times)$. Barnacle cirri are biramous appendages (Crisp \& Maclean 1990). For Balanus amphitrite, both rami of each of the 3 cirri that we measured were of similar length and had the same number of segments. The lengths of the 2 constituent rami were therefore recorded, and the average of the 2 measurements was used in the correlation analysis with basal diameter. We examined 18 juveniles of all sizes for each delay of metamorphosis treatment (Days 0 and 4). Linear regression analysis was used to describe the relationships between juvenile basal diameter and length of each feeding cirri. To test whether the slope of the regressions of juvenile feeding cirrus length versus juvenile basal diameter was significantly different between juveniles whose cyprids were forced to delay metamorphosis for 0 and $4 \mathrm{~d}$, an ANCOVA was used as described in Zar (1999).

Expt 5-effect of delayed metamorphosis on juvenile feeding rate. Since a $4 \mathrm{~d}$ delay in metamorphosis dramatically depressed post-metamorphic growth in previous experiments (e.g. Pechenik et al. 1993), this experiment examined whether the effect on growth occurs because cyprids that experience delayed metamorphosis develop into juveniles with reduced feeding capabilities. This experiment was done from April to June 2006 using cyprids obtained from the third batch larvae of Expt 3. Cyprids were allowed to metamorphose on either Day 0 or 4 on polystyrene Petri dishes $(90 \mathrm{~mm} \times 15 \mathrm{~mm}$ ) and juveniles were then cultured for $5 \mathrm{~d}$ on a diet of Chaetoceros gracilis $\left(10^{5}\right.$ cells $\mathrm{ml}^{-1} ; 50 \mathrm{ml}$ dish $\left.^{-1}\right)$ at $28^{\circ} \mathrm{C}$. Nine replicate dishes were used per delayed metamorphosis treatment, each replicate containing 30 to 40 juveniles. Filtration rates of the $5 \mathrm{~d}$ old juveniles were determined from the decline in chlorophyll in surrounding water during a $6 \mathrm{~h}$ experimental period. 
Filtration rate $\left(\mathrm{FR}_{;} \mathrm{ml} \mathrm{h} \mathrm{h}^{-1}\right)$ was determined by the equation from Coughlan (1969):

$$
\mathrm{FR}=\mathrm{Vol}\left[\left(\ln C_{0}-\ln C_{1}\right)-\left(\ln C_{0}{ }^{\prime}-\ln C_{1}{ }^{\prime}\right)\right] / t
$$

where $\mathrm{Vol}$ is the volume of seawater in the aquaria $(\mathrm{ml}), t$ is time (h), $C_{0}$ is the initial chl $a$ in the experimental aquaria $\left(\mu \mathrm{g} \mathrm{l}^{-1}\right), C_{1}$ is the final chl $a$ in the experimental aquaria $\left(\mu \mathrm{g} \mathrm{l}^{-1}\right), C_{0}{ }^{\prime}$ is the initial chl $a$ in the control aquaria $\left(\mu \mathrm{g} \mathrm{l}^{-1}\right.$ ) and $C_{1}{ }^{\prime}$ is the final chl $a$ in the control aquaria $\left(\mu \mathrm{g} \mathrm{l}^{-1}\right)$. In this equation, the mean changes in control concentrations (without juveniles) were subtracted from the changes in experimental concentrations (with juveniles). At the end of the experiment, filtration rates were divided by the total number of juveniles in each dish to obtain a filtration rate in millilitres per juvenile per hour. ANOVA was used to test for significant difference in filtration rates between treatments.

\section{RESULTS}

\section{Expt 1 -cyprid energy reserves, metamorphosis and juvenile growth}

Prolonging the swimming period of Balanus amphitrite cyprids by $24 \mathrm{~h}$ at 34 psu did not significantly reduce cyprid lipid content relative to controls (Fig. 1A) for any of the 3 batches of larvae tested (Dunnett test, $\mathrm{p}>0.05)$, but did result in a lower percent metamorphosis in 2 of the 3 batches of larvae (Fig. 1B:
Batches 1 and 3). Prolonging the swimming period of cyprids for $3 \mathrm{~d}$ at 34 psu significantly reduced cyprid lipid content regardless of the salinity in which cyprids were held for $24 \mathrm{~h}$ after the delay period (Fig. 1A, Table 1), as well as percent metamorphosis in 2 of the 3 batches of larvae (Fig. 1B: Batches 1 and 3). Exposure of 0 or $3 \mathrm{~d}$ old cyprids to the lowest salinity (10 psu) for $24 \mathrm{~h}$ had no significant effect on final cyprid lipid reserves (Table 1); however, such exposure significantly increased the proportion of larvae that metamorphosed, relative to controls, in 2 of the 3 batches of larvae (Fig. 1B, Tables 1 \& 2).

Delayed metamorphosis and low-salinity treatments affected all 3 juvenile growth parameters in at least 2 of the 3 larval batches, with total DW and AFDW being the most significantly affected (Fig. 2). There was a strong interaction between delayed metamorphosis and salinity treatment effects on juvenile tissue growth rates (i.e. DW and AFDW). Between the 2 factors, delayed metamorphosis caused more variation in growth rates than did the salinity treatment, as indicated by the MS values in Table 1.

Growth rates of juveniles derived from $0 \mathrm{~d}$ old cyprids that were exposed to the lowest salinity (10 psu) for $24 \mathrm{~h}$ were considerably lower than for control juveniles, particularly with respect to total DW and AFDW (Fig. 2, Table 2). However, exposure of $3 \mathrm{~d}$ old cyprids to the lowest salinity had inconsistent effects on juvenile growth rates among the 3 batches of larvae (Table 2). Nevertheless, delayed metamorphosis itself had a significant negative effect on final juvenile DW
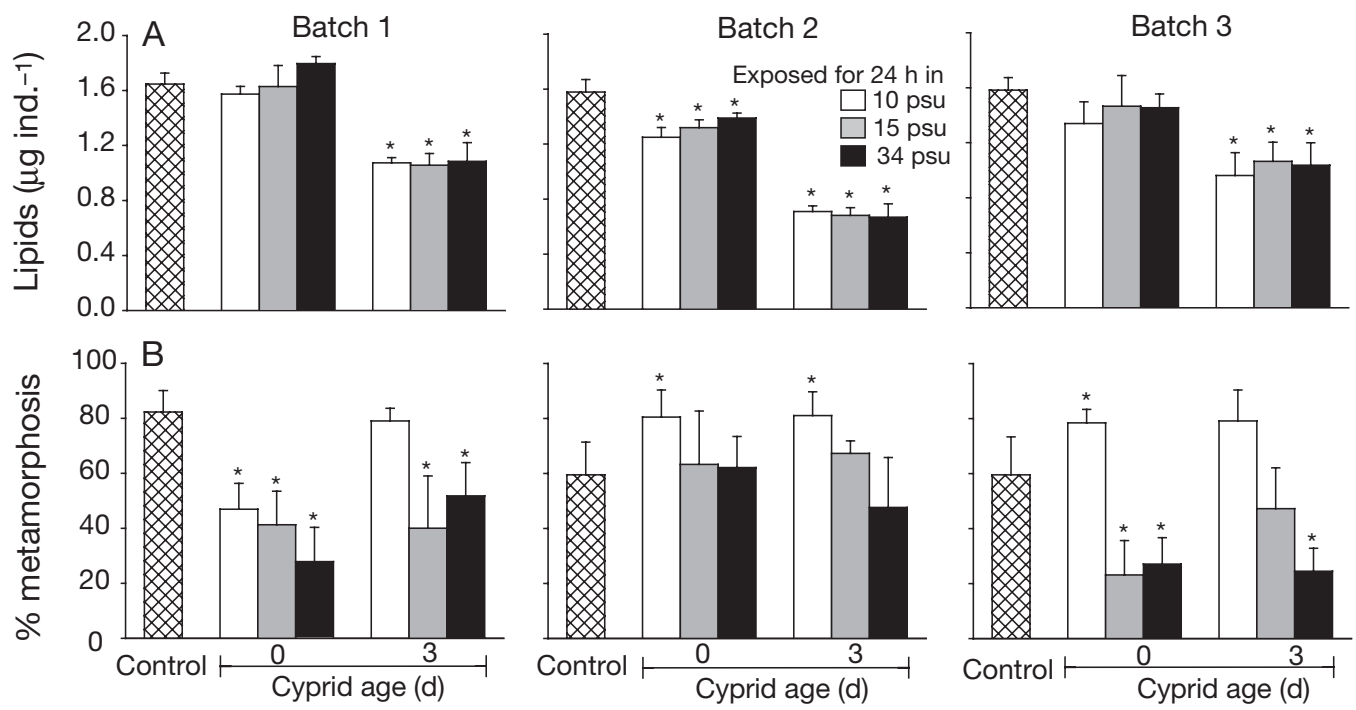

Fig. 1. Balanus amphitrite. (A) Combined effects of delayed metamorphosis (2 levels: 0 and 3 d) and exposure to various salinities (3 levels: 10, 15 and $34 \mathrm{psu}$ ) for $24 \mathrm{~h}$ on cyprid lipid content (proxy of cyprid energy reserves) and (B) percent metamorphosis on polystyrene dishes. No delay of metamorphosis occurred in control treatment. Data are mean $( \pm \mathrm{SD})$ of 3 to 6 replicates, each of which contained 20 to 50 cyprids. Significant differences between treatment and control are marked by asterisk (Dunnett test,

$$
\mathrm{p}<0.05)
$$


and AFDW in 13 out of 18 comparisons (3 levels of salinity $\times 3$ larval batches $\times 2$ levels of growth measurements: DW and AFDW; Table 2). For example, delaying metamorphosis for $3 \mathrm{~d}$ in $34 \mathrm{psu}$ and then maintain- ing larvae for an additional $24 \mathrm{~h}$ at various salinities (including $34 \mathrm{psu}$ ) significantly reduced juvenile final DW and AFDW compared with those measurements in control individuals (Fig. 2; Dunnett tests, $\mathrm{p}<0.05$ ).

Table 1. Balanus amphitrite. 2-way ANOVA comparing effects of delayed metamorphosis (2 levels: 0 and 3 d) and exposure to various salinities (3 levels: 10, 15 and $34 \mathrm{psu}$ ) for $24 \mathrm{~h}$ on cyprid energy reserves (lipid content), metamorphosis, juvenile basal diameter, juvenile dry weight (DW) and ash-free dry weight (AFDW) after $5 \mathrm{~d}$ post-metamorphosis. Data were square-root transformed to meet ANOVA assumptions. Bold: significant $\left({ }^{\mathrm{ns}} \mathrm{p}>0.05{ }_{i}{ }^{*} \mathrm{p}<0.05_{i}{ }^{* *} \mathrm{p}<0.01_{i}{ }^{* * *} \mathrm{p}<0.001\right)$. DM: delayed metamorphosis

\begin{tabular}{|c|c|c|c|c|c|c|c|c|c|c|c|c|c|c|c|}
\hline \multirow[t]{2}{*}{ Source } & \multicolumn{3}{|c|}{ Energy reserves } & \multicolumn{3}{|c|}{ Metamorphosis } & \multicolumn{3}{|c|}{ Basal diameter } & \multicolumn{3}{|c|}{ Juvenile DW } & \multicolumn{3}{|c|}{ Juvenile AFDW } \\
\hline & df & MS & $F$ & $\mathrm{df}$ & MS & $F$ & $\mathrm{df}$ & MS & $F$ & df & MS & $F$ & df & MS & $F$ \\
\hline \multicolumn{16}{|l|}{ Batch 1} \\
\hline DM & 1 & 0.293 & $160.89^{* * *}$ & 1 & 1070.3 & $17.13^{* * *}$ & 1 & 0.006 & $5.82^{*}$ & 1 & 0.119 & $28.17^{* * *}$ & 1 & 0.303 & $278.54^{* * *}$ \\
\hline Salinity & 2 & 0.003 & $1.96^{\mathrm{ns}}$ & 2 & 795.2 & $12.75^{* * *}$ & 2 & 0.012 & $10.45^{* * *}$ & 2 & 0.051 & $12.27^{* * *}$ & 2 & 0.001 & $1.01^{\mathrm{ns}}$ \\
\hline $\mathrm{DM} \times$ Salinity & 2 & 0.002 & $1.40^{\mathrm{ns}}$ & 2 & 364.3 & $5.84^{* * *}$ & 2 & 0.001 & $0.84^{\mathrm{ns}}$ & 2 & 0.092 & $22.03^{* * *}$ & 2 & 0.027 & $25.73^{* * *}$ \\
\hline Error & 12 & 0.001 & 30 & 62.3 & 24 & 0.001 & 18 & 0.004 & 18 & 0.001 & & & & & \\
\hline \multicolumn{16}{|l|}{ Batch 2} \\
\hline DM & 1 & 0.463 & $376.97^{* * *}$ & 1 & 40.9 & $0.61^{\mathrm{ns}}$ & 1 & 0.058 & $62.49^{* * *}$ & 1 & 0.272 & $26.73^{* * *}$ & 1 & 0.034 & $42.84^{* * *}$ \\
\hline Salinity & 2 & 0.001 & $0.38^{\mathrm{ns}}$ & 2 & 847.6 & $12.77^{* * *}$ & 2 & 0.006 & $6.46^{* * *}$ & 2 & 0.062 & $6.15^{* * *}$ & 2 & 0.048 & $60.05^{* * *}$ \\
\hline $\mathrm{DM} \times$ Salinity & 2 & 0.002 & $2.32^{\mathrm{ns}}$ & 2 & 101.2 & $1.52^{\mathrm{ns}}$ & 2 & 0.001 & $1.53^{\mathrm{ns}}$ & 2 & 0.171 & $16.69^{* * *}$ & 2 & 0.021 & $26.31^{* * *}$ \\
\hline Error & 12 & 0.001 & 30 & 66.3 & 24 & 0.001 & 18 & 0.001 & 18 & 0.001 & & & & & \\
\hline \multicolumn{16}{|l|}{ Batch 3} \\
\hline DM & 1 & 0.149 & $26.87^{* * *}$ & 1 & 261.6 & $3.91^{\mathrm{ns}}$ & 1 & 0.001 & $0.767^{\mathrm{ns}}$ & 1 & 0.631 & $13.92^{* * *}$ & 1 & 0.045 & $19.76^{* * *}$ \\
\hline Salinity & 2 & 0.004 & $0.84^{\mathrm{ns}}$ & 2 & 3760.4 & $56.09^{* * *}$ & 2 & 0.001 & $2.31^{\mathrm{ns}}$ & 2 & 0.012 & $1.02^{\mathrm{ns}}$ & 2 & 0.011 & $4.89^{*}$ \\
\hline $\mathrm{DM} \times$ Salinity & 2 & 0.001 & $0.01^{\mathrm{ns}}$ & 2 & 307.2 & $4.58^{*}$ & 2 & 0.002 & $3.07^{\mathrm{ns}}$ & 2 & 0.079 & $6.75^{* * *}$ & 2 & 0.056 & $24.32^{* * *}$ \\
\hline Error & 12 & 0.005 & 30 & 67.1 & 24 & 0.001 & 18 & 0.011 & 18 & 0.002 & & & & & \\
\hline
\end{tabular}
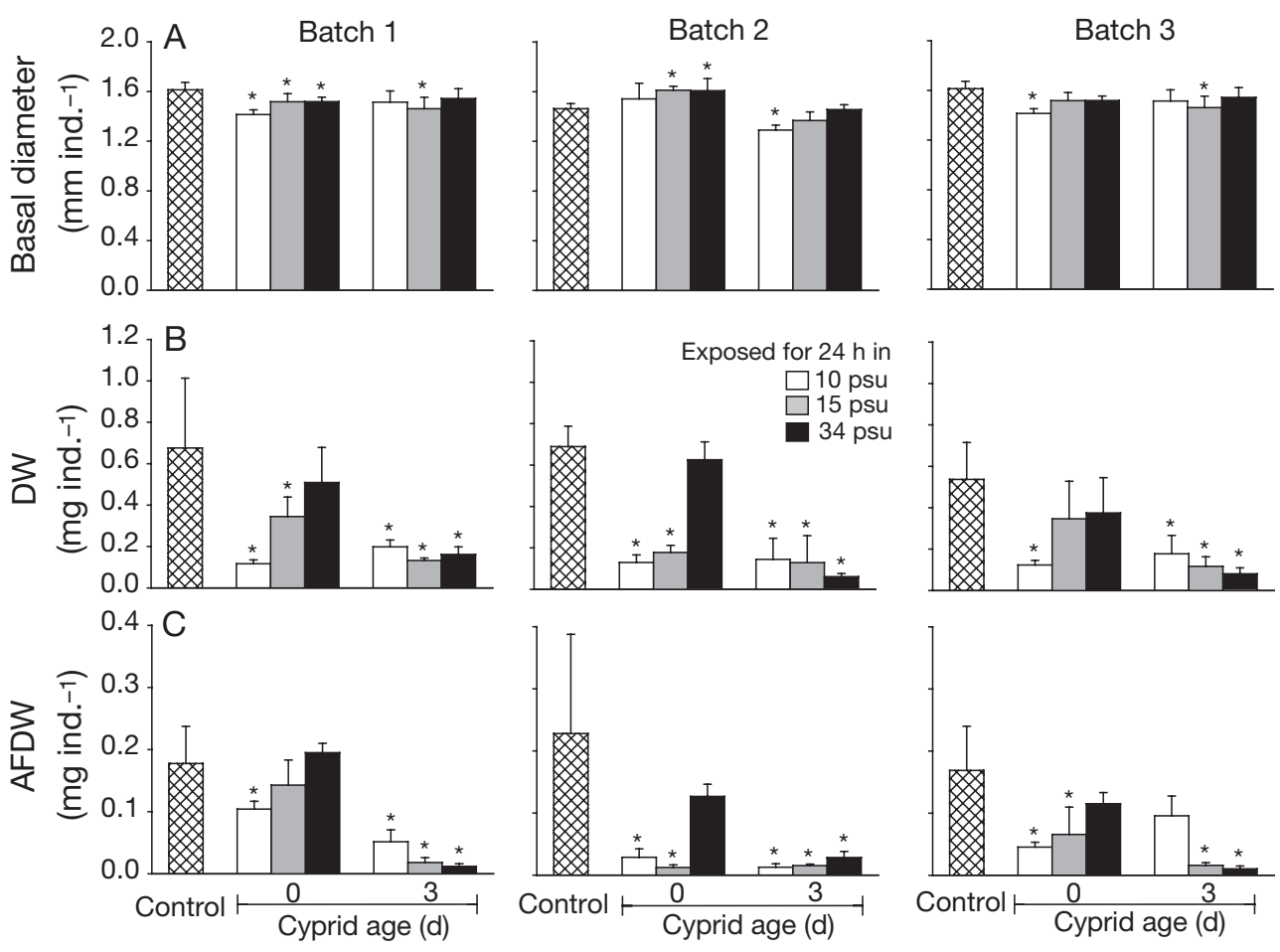

Fig. 2. Balanus amphitrite. Combined effects of delayed metamorphosis (2 levels: 0 and $3 \mathrm{~d}$ ) and exposure to various salinities (3 levels: 10, 15 and $34 \mathrm{psu}$ ) for $24 \mathrm{~h}$ on (A) juvenile basal diameter, (B) dry weight (DW) and (C) ash-free dry weight (AFDW), after 5 d post-metamorphosis. No delay of metamorphosis occurred in control treatment. Data are final means ( \pm SD) of 4 to 5 replicates, each of which contained 10 to 25 juveniles. ${ }^{*}$ Significant differences between treatment and control (Dunnett test, $\left.\mathrm{p}<0.05\right)$ 
Table 2. Balanus amphitrite. Tukey's multiple comparison test or 1-way ANOVA: effects of delayed metamorphosis (2 levels: 0 and $3 \mathrm{~d}$ ) and exposure to various salinities (3 levels: 10, 15 and $34 \mathrm{psu}$ ) for $24 \mathrm{~h}$ on cyprid energy reserves (lipid content), metamorphosis, juvenile basal diameter, juvenile dry and ash-free dry weight (DW and AFDW, respectively) after $5 \mathrm{~d}$ post-metamorphosis. Underlines: treatment means that are not significantly different. Results are shown for 3 batches (B1 to B3) of larvae

\begin{tabular}{|c|c|c|c|c|c|c|c|c|c|c|c|c|c|c|c|c|}
\hline \multirow{2}{*}{$\frac{\text { Treatment }}{\text { Delayed }}$} & \multirow[t]{2}{*}{ Batch } & \multicolumn{3}{|c|}{ Energy reserves } & \multicolumn{3}{|c|}{ Metamorphosis } & \multicolumn{3}{|c|}{ Basal diameter } & \multicolumn{3}{|c|}{ DW } & \multicolumn{3}{|c|}{ AFDW } \\
\hline & & & & & & & & & & & & & & & & \\
\hline \multirow[t]{3}{*}{$0 \mathrm{~d}$} & B1 & $\underline{10}$ & 15 & 34 & $\underline{34}$ & 15 & 10 & $\underline{10}$ & $\underline{15}$ & 34 & $\underline{10}$ & 15 & 34 & $\underline{10}$ & $\underline{15}$ & 34 \\
\hline & B2 & 10 & 15 & 34 & $\underline{34}$ & 15 & 10 & 10 & 34 & 15 & 10 & 15 & $\underline{34}$ & $\underline{15}$ & $\underline{10}$ & 34 \\
\hline & B3 & $\underline{15}$ & 34 & 10 & 15 & 34 & $\underline{10}$ & $\underline{10}$ & $\underline{15}$ & 34 & $\underline{10}$ & $\underline{15}$ & $\overline{34}$ & $\underline{10}$ & $\underline{15}$ & 34 \\
\hline \multirow[t]{3}{*}{$3 \mathrm{~d}$} & B1 & 15 & 10 & 34 & $\underline{15}$ & 34 & $\underline{10}$ & 15 & 10 & 34 & 15 & 34 & 10 & 34 & 15 & $\underline{10}$ \\
\hline & B2 & 34 & 15 & 10 & 34 & 15 & $\underline{10}$ & 10 & 15 & 34 & 34 & 15 & 10 & 10 & 15 & 34 \\
\hline & B3 & $\underline{15}$ & 34 & 10 & $\underline{34}$ & $\underline{15}$ & $\underline{10}$ & $\underline{15}$ & $\overline{10}$ & 34 & $\underline{34}$ & 15 & 10 & 34 & 15 & $\underline{10}$ \\
\hline \multicolumn{17}{|l|}{ Salinity } \\
\hline \multirow[t]{3}{*}{$10 \mathrm{psu}$} & B1 & $\underline{3}$ & $\underline{0}$ & & $\underline{0}$ & $\underline{3}$ & & $\underline{0}$ & 3 & & $\underline{0}$ & $\underline{3}$ & & $\underline{3}$ & $\underline{0}$ & \\
\hline & B2 & $\underline{3}$ & $\underline{0}$ & & $\underline{0}$ & $\overline{3}$ & & $\underline{3}$ & $\underline{0}$ & & $\underline{0}$ & 3 & & 3 & 0 & \\
\hline & B3 & $\underline{3}$ & $\underline{\overline{0}}$ & & $\underline{0}$ & 3 & & $\underline{0}$ & $\overline{3}$ & & $\underline{0}$ & 3 & & $\underline{0}$ & $\underline{3}$ & \\
\hline \multirow[t]{3}{*}{$15 \mathrm{psu}$} & B1 & $\underline{3}$ & $\underline{0}$ & & $\underline{0}$ & 3 & & $\underline{3}$ & 0 & & $\underline{3}$ & $\underline{0}$ & & $\underline{3}$ & $\underline{0}$ & \\
\hline & B2 & $\underline{\overline{3}}$ & $\underline{\overline{0}}$ & & 3 & $\underline{0}$ & & $\underline{3}$ & $\underline{0}$ & & $\underline{3}$ & $\overline{0}$ & & $\underline{\overline{0}}$ & $\underline{3}$ & \\
\hline & B3 & $\underline{3}$ & $\underline{\overline{0}}$ & & $\underline{0}$ & 3 & & $\underline{3}$ & $\overline{0}$ & & $\underline{3}$ & $\underline{0}$ & & $\underline{3}$ & $\underline{0}$ & \\
\hline \multirow[t]{3}{*}{$34 \mathrm{psu}$} & B1 & $\underline{3}$ & $\underline{0}$ & & $\underline{0}$ & $\underline{3}$ & & $\underline{0}$ & 3 & & $\underline{3}$ & $\underline{0}$ & & $\underline{3}$ & $\underline{0}$ & \\
\hline & B2 & $\underline{3}$ & $\underline{0}$ & & $\underline{0}$ & 3 & & $\underline{3}$ & $\underline{0}$ & & $\underline{3}$ & $\underline{0}$ & & $\underline{3}$ & $\underline{0}$ & \\
\hline & B3 & $\underline{3}$ & $\underline{0}$ & & $\underline{0}$ & 3 & & $\underline{0}$ & 3 & & $\underline{3}$ & $\underline{0}$ & & $\underline{3}$ & $\underline{0}$ & \\
\hline
\end{tabular}

\section{Expt 2-growth of juveniles outplanted into the field}

Delaying metamorphosis for $3 \mathrm{~d}$ had a significant negative effect on final mean juvenile basal diameter and DW and AFDW, regardless of the salinity treatment (Fig. 3; Student's $t$-tests, $\mathrm{p}<0.05$ ). Interestingly, the final mean AFDW of juveniles derived from cyprids that were delayed for $3 \mathrm{~d}$ in $34 \mathrm{psu}$ and then exposed to the lowest salinity $(10 \mathrm{psu})$ for $24 \mathrm{~h}$ was not significantly different from individuals derived from cyprids that were not delayed but were exposed to the same salinity treatment (Fig. 3C; Student's $t$-test, $\mathrm{p}>0.05)$. Exposing $0 \mathrm{~d}$ old cyprids to the lowest salinity for $24 \mathrm{~h}$ significantly reduced final mean DW and AFDW compared to control individuals (Fig. 3B,C).

\section{Expt 3-juvenile growth in sites differing in food availability}

Nutritional conditions, including food quality and quantity, differed significantly between the 2 study sites. The OA site was organically richer than the UST site, as shown by significantly higher TOC $(2.5 \pm 0.4 \mu \mathrm{g}$ $\left.\mathrm{l}^{-1}\right)$ and chl a $\left(1.52 \pm 0.32 \mu \mathrm{g} \mathrm{l}^{-1}\right)$. During the experimental period, TOC and chl a contents at UST varied from 1.2 to $1.5 \mu \mathrm{g}^{-1}$ and 0.42 to $0.61 \mu \mathrm{g} \mathrm{l^{-1 }}$, respectively. Similarly, the food quality (measured as the $\mathrm{C} / \mathrm{N}$ ratio) was significantly lower at OA $(4.5 \pm 0.34)$ than at UST $(6.2 \pm 0.6)$. However, the surface water temperature

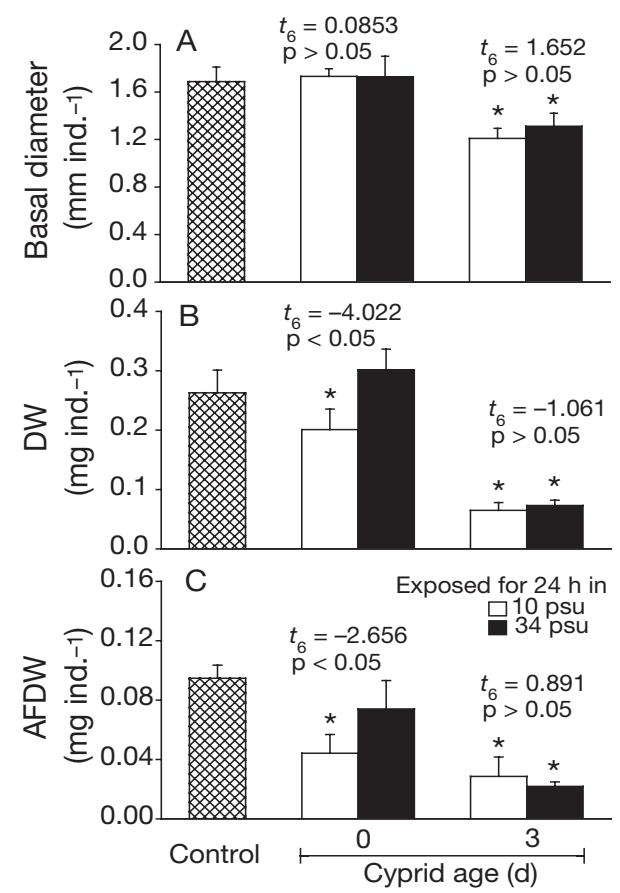

Fig. 3. Balanus amphitrite. Combined effects of delayed metamorphosis ( 2 levels: 0 and $3 \mathrm{~d}$ ) and exposure to various salinities (2 levels: 10 and 34 psu) for $24 \mathrm{~h}$ on (A) juvenile basal diameter, (B) dry weight (DW) and (C) ash-free dry weight (AFDW) after $5 \mathrm{~d}$ post-metamorphosis. No delay of metamorphosis occurred in control treatment. Data are final means $( \pm \mathrm{SD})$ of 4 to 5 replicates, each of which contained 10 to 25 juveniles. "Significant differences between treatment and control (Dunnett test, $\mathrm{p}<0.05$ ). Significant differences between salinity treatments within each cyprid age group are compared using Student's $t$-tests 
$\left(25 \pm 3^{\circ} \mathrm{C}\right)$ and salinity $(32 \pm 1 \mathrm{psu})$ did not differ significantly between these 2 sites during the study period (Student's $t$-test, $\mathrm{p}>0.05$ ).

Both delayed metamorphosis and juvenile habitats differing in food availability had significant effects on

Table 3. Balanus amphitrite. 2-way ANOVA comparing effects of delayed metamorphosis ( 2 levels: 0 and 4 d) and food availability in juvenile habitat (2 levels: University of Science and Technology site-low food availability; Old Airport site-high food availability) on juvenile dry weight (DW) and ash-free dry weight (AFDW) after $5 \mathrm{~d}$ post-metamorphosis. Data were square-root transformed to meet ANOVA assumptions. Bold: significant $\left({ }^{n s} \mathrm{p}>0.05 ;{ }^{* * *} \mathrm{p}<0.001\right)$. DM: delayed metamorphosis

\begin{tabular}{|c|c|c|c|c|c|}
\hline \multirow{2}{*}{ Source } & \multirow{2}{*}{$\mathrm{df}$} & \multicolumn{2}{|c|}{$-\mathrm{DW}-$} & \multicolumn{2}{|c|}{ _ AFDW } \\
\hline & & MS & $F$ & MS & $F$ \\
\hline $\mathrm{DM}$ & 1 & 0.696 & $137.71^{* * *}$ & 0.126 & $71.18^{* * *}$ \\
\hline Juvenile habitat & 1 & 0.161 & $31.65^{* * *}$ & 0.016 & $88.89^{* * *}$ \\
\hline $\mathrm{DM} \times$ Habitat & 1 & 0.001 & $0.02^{\mathrm{ns}}$ & 0.001 & $0.02^{\mathrm{ns}}$ \\
\hline Error & 32 & 0.005 & 0.001 & & \\
\hline
\end{tabular}
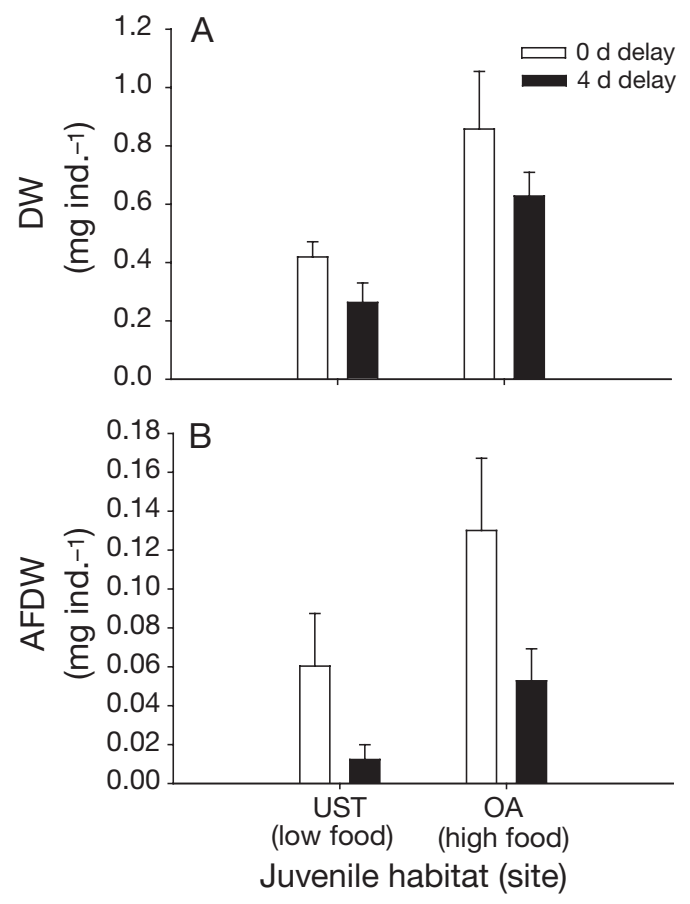

Fig. 4. Balanus amphitrite. Combined effects of delayed metamorphosis ( 2 levels: 0 and $4 \mathrm{~d}$ ) and food availability in juvenile habitat (2 levels: UST and OA) on (A) juvenile dry weight (DW) and (B) ash-free dry weight (AFDW) after $5 \mathrm{~d}$ post-metamorphosis. Data are means $( \pm \mathrm{SD})$ of 9 replicate plates $(3$ larval batches $\times 3$ replicate plates per larval batch). The final dry and ash-free dry weight of all individuals within a plate (10 to 20 ind. plate ${ }^{-1}$ ) were pooled. UST: University of Science and Technology; OA: Old Airport juvenile growth, with no interaction between these 2 factors (Table 3). As observed in Expt 2, delayed metamorphosis had a dramatic negative effect on juvenile growth, as determined by the final DW and AFDW measurements (Fig. 4). After 5 d post-metamorphosis, juveniles derived from cyprids that had been delayed for $4 \mathrm{~d}$ had much lower growth rates than those that were induced to metamorphosis on Day 0. In addition, juvenile growth at the high-nutrient site (OA) was $>2$ times that of juveniles maintained at the low-nutrient site (UST), whether or not metamorphosis had been delayed. However, the effect of delayed metamorphosis appeared to be relatively stronger at UST where less food was available to juveniles, with DW and AFDW being, respectively, $\sim 37$ and $80 \%$ lower than the respective values in controls, whereas DW and AFDW at OA were $\sim 27$ and
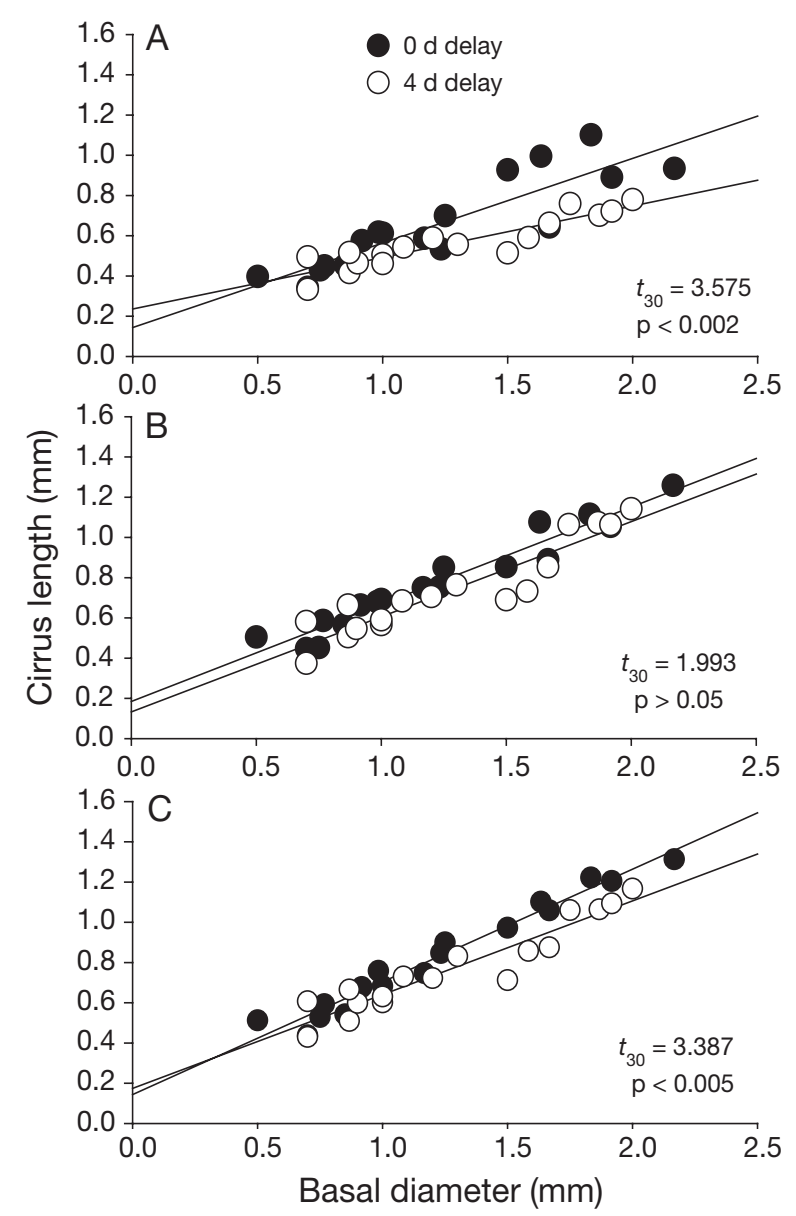

Fig. 5. Balanus amphitrite. Relationship between juvenile basal diameter and cirrus length (A: Cirrus IV; B: Cirrus V; C: Cirrus VI) in juveniles derived from cyprids that had not (-: 0 d) or had (O: 4 d) been forced to delay their metamorphosis. Regression parameters are given in Table 4. Slopes of 2 regression lines in each figure were compared using ANCOVA (analogous to $t$-test) 
Table 4. Balanus amphitrite. Regression details for relationship between juvenile basal diameter (independent variable: $\mathrm{mm}$ ind. ${ }^{-1}$ ) and length of juvenile cirrus (IV, V and VI; dependent variables: $\mathrm{mm}$ ind.$^{-1}$ ) in juveniles $(5 \mathrm{~d}$ postmetamorphosis) derived from cyprids that had not ( 0 d delay) or had (4 d delay) been forced to delay their metamorphosis. Parentheses: SE. Bold: significant

\begin{tabular}{|lrcccr|}
\hline Type & N & Intercept & Slope & $R^{2}$ & \multicolumn{1}{c|}{$F_{1,17}$} \\
\hline $\mathbf{0 ~ d ~ d e l a y ~}$ & & & & & \\
Cirrus IV & 17 & $0.143(0.075)$ & $0.421(0.075)$ & 0.78 & $\mathbf{5 3 . 6 5}$ \\
Cirrus V & 17 & $0.184(0.043)$ & $0.483(0.043)$ & 0.93 & $\mathbf{2 2 1 . 6 8}$ \\
Cirrus VI & 17 & $0.144(0.036)$ & $0.561(0.036)$ & 0.96 & $\mathbf{4 1 0 . 9 2}$ \\
$\mathbf{4}$ d delay & & & & & \\
Cirrus IV & 17 & $0.236(0.041)$ & $0.256(0.041)$ & 0.82 & $\mathbf{7 1 . 8 3}$ \\
Cirrus V & 17 & $0.133(0.066)$ & $0.473(0.066)$ & 0.86 & $\mathbf{9 5 . 4 9}$ \\
Cirrus VI & 17 & $0.174(0.056)$ & $0.466(0.056)$ & 0.89 & $\mathbf{1 2 7 . 3 6}$ \\
\hline
\end{tabular}

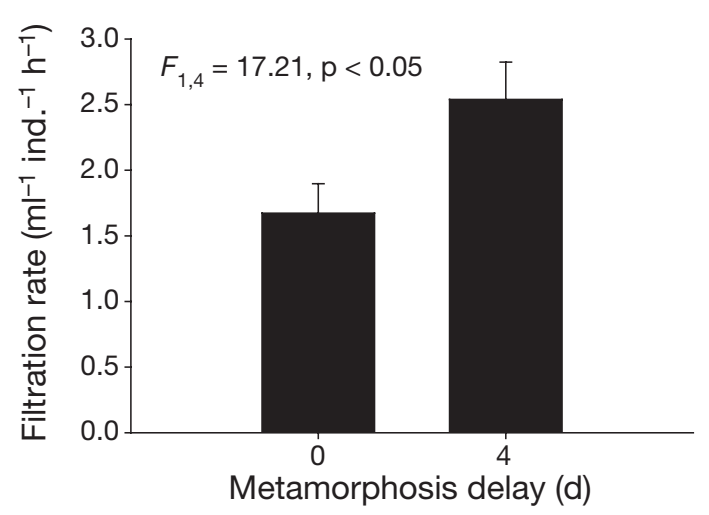

Fig. 6. Balanus amphitrite. Effect of delayed metamorphosis (2 levels: 0 and $4 \mathrm{~d}$ ) on juvenile feeding rates after $5 \mathrm{~d}$ of postmetamorphosis. Data are means $( \pm \mathrm{SD})$ of 3 replicates, each of which contained 30 to 45 juveniles

$60 \%$ lower than the respective values in controls. At both sites, delayed metamorphosis had a greater effect on the final AFDW than on the final total DW (Fig. 4).

\section{Expt 4-relationship between basal diameter and feeding cirrus length}

There was a strong positive correlation between juvenile cirrus length (i.e. Cirrus IV, V and VI) and juvenile basal diameter for juveniles from both treatments ( 0 or $4 \mathrm{~d}$ delay of metamorphosis) (Fig. 5, Table $4 ; \mathrm{R}^{2}=0.78$ to 0.96 ). Delaying metamorphosis had a small, but significant effect on the final length of Cirrus IV and VI, but not Cirrus V, i.e. the slopes of the regression lines for juveniles derived from Day 0 and 4 cyprids were significantly different from each other
(Fig. 5). The cirrus lengths of juveniles were shorter than expected if cyprids had been forced to delay their metamorphosis.

\section{Expt 5-juvenile filtration rates}

Delayed metamorphosis had a significant effect on the average feeding rate of $5 \mathrm{~d}$ old juveniles, but in an unexpected direction: juveniles derived from delayed larvae filtered particles comparatively faster than did the control individuals (Fig. 6).

\section{DISCUSSION}

\section{Delayed metamorphosis}

Delaying the metamorphosis of Balanus amphitrite cyprids by 3 to $4 \mathrm{~d}$ severely depressed subsequent early juvenile growth rates, consistent with findings in earlier studies (Pechenik et al. 1993, Thiyagarajan et al. 2003a). In addition, we found that the effects of delayed metamorphosis were not just laboratory artefacts: the effects persisted for at least $5 \mathrm{~d}$ after metamorphosis when early juveniles were outplanted to the field. Detrimental effects of delayed metamorphosis on early juvenile growth rates are important because slow growth not only increases the probability of predation, but also substantially diminishes competitive ability in the population (Connell 1961, Bertness 1989, Miller \& Carefoot 1989, Pechenik 1990).

\section{Delayed metamorphosis versus nutrient condition in juvenile habitat}

Growth rates of early juvenile barnacles may depend on energy reserves carried over from the larval stage, as well as on food availability to the early juvenile in the benthic habitat (Denley \& Underwood 1979, Jarrett 2003, Thiyagarajan et al. 2003a,b). We had therefore speculated that when nutritional conditions are favourable in the juvenile habitat, the detrimental effects of delayed metamorphosis might be partly or entirely compensated for by the availability of abundant, high-quality food in the habitat. On the other hand, if delayed larvae metamorphose in a lownutrient habitat, early juveniles may suffer from the additive effects of delayed metamorphosis and nutritional stress. In our study, juveniles derived from delayed cyprids grew much more slowly than control juveniles, even at the site with the greatest food availability. The negative effect of delayed metamorphosis was only marginally less pronounced at the nutrient- 
rich habitat (OA) than at the nutrient-poor habitat (UST), indicating that early juveniles cannot make up for the deleterious effects of delayed metamorphosis through increased uptake of food in habitats with abundant, high-quality food. This is consistent with findings by Emlet \& Sadro (2006), who demonstrated that higher food availability to early juveniles did not negate the detrimental effects of poor larval feeding history in barnacles, and by Phillips (2002), who showed that favourable intertidal habitats (i.e. with high food availability and reduced aerial exposure) did not compensate for the detrimental effects of larval nutritional history on post-metamorphic growth rates in marine mussels.

\section{Mediation of the effects of delayed metamorphosis}

The last 3 pairs of cirral appendages of barnacles constitute the captorial cirrial net involved in filter feeding (Anderson 1994). As previously shown for temperate (Crisp \& Maclean 1990) and subtropical (Chan \& Hung 2005) barnacle species, we observed a significant linear increase in cirral length with individual basal diameter for Balanus amphitrite. Increments of Cirrus IV and VI with 1 unit of individual basal diameter (i.e. slope of the regression lines in Table 4) in delayed individuals were marginally smaller than those exhibited by control barnacles, but showed no difference in the increments of Cirrus $\mathrm{V}$ between the 2 groups. The length of feeding cirri is likely to affect their ability to act as effective filters (Li \& Denny 2004). Therefore, it was expected that delayed individuals may have a significantly lower feeding rate than that of control juveniles. Unexpectedly, the mean filtration rate of delayed individuals was significantly higher than that of controls. Thus, differences in the dimensions of their captorial cirral net or by their rate of filtration do not explain the slow juvenile growth rate of individuals experiencing delayed metamorphosis as larvae. In bryozoans, however, delayed metamorphosis did significantly reduce the dimensions of juvenile feeding appendages, which ultimately influenced juvenile fitness (Wendt 1996). Similarly, a delay in metamorphosis and an increase in swimming activity produced ascidian colonies with 10 to $15 \%$ smaller feeding structures (Marshall et al. 2003). Juvenile barnacles resulting from larvae that have delayed their metamorphosis may exhibit reduced assimilation efficiency rather than reduced feeding rates, but that suggestion requires future investigation. A recent study on slipper limpets showed that adverse effects of larval feeding history are not mediated by low food assimilation efficiency (Chiu et al. 2007). Alternatively, reduced growth in delayed individuals might result from the impairment of such biochemical characteristics as the enzymes responsible for modulating tissue growth (Roberts \& Lapworth 2001).

\section{Latent effects of larval exposure to low-salinity stress}

In this study, acute exposure to low salinities did not reduce cyprid lipid energy reserves; cyprids might have used protein reserves instead of lipids (Satuito et al. 1996), while delaying their metamorphosis. Alternatively, osmotic regulation by cyprids may not require large amounts of energy, or cyprids may have compensated for increased energetic costs due to osmoregulation by reducing swimming activity. Also, exposure of cyprids to the low salinities tested in our study does not cause higher mortality, but does decrease larval activity (Qiu \& Qian 1999), so that reduced activity may have compensated for elevated energy expenditure in osmoregulation. Interestingly, exposure to the lowest salinity (10 psu) significantly promoted metamorphosis after transfer to full-strength seawater. The mechanism responsible for this response is not known; however, a similar effect of low salinity has been observed in larvae of some other marine invertebrates (Wolcott \& DeVries 1994, Pechenik et al. 2001).

Most importantly, acute exposure of $0 \mathrm{~d}$ delayed cyprids to the lowest salinity stress (i.e. $10 \mathrm{psu}$ ) for $24 \mathrm{~h}$ consistently reduced post-metamorphic growth rate by as much as $70 \%$ relative to non-stressed cyprids. The combined effects of salinity stress and delayed metamorphosis on juvenile growth in the laboratory were similar in most respects to the effects observed in individuals outplanted to the field. However, contrary to our prediction that acute exposure to low salinity would be more detrimental for cyprids that delayed metamorphosis for $3 \mathrm{~d}$ than for cyprids with no delay, there was no synergistic effect between these 2 factors. Although it has often been suggested that the latent effects of delayed metamorphosis are mediated through depletion of energy stores (reviewed in Pechenik 2006, Wendt \& Johnson 2006), our results suggest that slower juvenile growth rates of barnacle juveniles in response to acute exposure to low-salinity stress and to delayed metamorphosis may not be mediated through depletion of energy reserves, i.e. exposing cyprids to low salinity did not reduce their energy reserves, but juvenile growth rate was nevertheless reduced as profoundly as for delayed individuals. Rather, this may be a consequence of reduced assimilation efficiency; future measurements of juvenile assimilation potential after exposure to different salinities should show whether this was a consequence of decreasing food-conversion efficiency. 
Salinity stress and delayed metamorphosis caused a reduction in juvenile growth rates, especially in terms of total DW and AFDW. Juvenile shell growth rate was also affected, although to a lesser extent, as previously observed (Pechenik et al. 1993). The less pronounced effect of delayed metamorphosis on juvenile growth in basal diameter suggests shell growth may be less sensitive to those effects than other growth measures such as tissue growth, measured as DW and AFDW. Also, our data indicate that shell growth can be uncoupled from tissue growth in this species, and Crisp \& Bourget (1985) also observed variations in tissue/shell growth rates in Semibalanus balanoides under different nutrient and salinity conditions. Thus, the basal diameter of juveniles seems a poor indicator of the effects of delayed metamorphosis or acute low-salinity stress.

In summary, 4 main points were highlighted by this study: (1) acute exposure of cyprids to low-salinity stress $(10 \mathrm{psu})$ increased the rate of attachment and metamorphosis; (2) both acute exposure of cyprids to low-salinity stress and delayed metamorphosis significantly reduced juvenile growth rates, but there was no interaction between these 2 factors; (3) negative effects of delayed metamorphosis on juvenile growth rates in Balanus amphitrite do not appear to be mediated by low feeding efficiency, reduced sizes of juvenile feeding appendages, or depletion of larval energy reserves at metamorphosis; and (4) surplus food availability in the juvenile habitat does not fully compensate for the negative effects of delayed metamorphosis on juvenile growth rates.

Acknowledgements. We thank J. M. Y. Chiu, O. S. Hung, F. S. Mok and L. Soo for discussions during the course of this project. The work described in this paper was funded by the Area of Excellence Scheme under the UGC of the Hong Kong SAR (Project No. AoE/P-04/2004) and an RGC grant (HKUST6418/ 06M) to P.Y.Q.

\section{LITERATURE CITED}

Anderson DT (1994) Barnacles: structure, function, development and evolution. Chapman \& Hall, London

Anger K (2003) Salinity as a key parameter in the larval biology of decapod crustaceans. Invertebr Reprod Dev 43: $29-45$

Bertness MD (1989) Intraspecific competition and facilitation in a northern acorn barnacle population. Ecology 70: 257-268

Chan BKK, Hung OS (2005) Cirral length of the acorn barnacle Tetraclita japonica (Cirripedia: Balanomorpha) in Hong Kong: effect of wave exposure and tidal height. J Crustac Biol 25:329-332

Chiu JMY, Ng TYT, Wang WX, Thiyagarajan V, Qian PY (2007) Latent effects of larval food limitation on filtration rate, carbon assimilation and growth in juvenile gastropod Crepidula onyx. Mar Ecol Prog Ser 343:173-182

Connell JH (1961) The influence of interspecific competition and other factors on the distribution of the barnacle Chthamalus stellatus. Ecology 42:710-723

Coughlan J (1969) The estimation of filtering rate from the clearance of suspensions. Mar Biol 2:356-358

Crisp DJ, Bourget E (1985) Growth in barnacles. Adv Mar Biol 22:199-244

Crisp DJ, Maclean FJ (1990) The relation between the dimensions of the cirral net, the beat frequency and the size and age of the animal in Balanus balanoides and Elminius modestus. J Mar Biol Assoc UK 70:505-514

Denley EJ, Underwood AJ (1979) Experiments on factors influencing settlement, survival, and growth of two species of barnacles in New South Wales. J Exp Mar Biol Ecol 36:269-293

Emlet RB, Sadro SS (2006) Linking stages of life history: how larval quality translates into juvenile performance for an intertidal barnacle (Balanus glandula) Integr Comp Biol 46:334-346

Gosselin LA, Qian PY (1996) Early post-settlement mortality of an intertidal barnacle: a critical period for survival. Mar Ecol Prog Ser 135:69-75

Jarrett JN (2003) Seasonal variation in larval condition and postsettlement performance of the barnacle Semibalanus balanoides. Ecology 84:384-390

Larsson AI, Jonsson PR (2006) Barnacle larvae actively select flow environments supporting post-settlement growth and survival. Ecology 87:1960-1966

Li NK, Denny MW (2004) Limits to phenotypic plasticity: flow effects on barnacle feeding appendages. Biol Bull (Woods Hole) 206:121-124

Marsh JB, Weinstein DB (1966) Simple charring method for determination of lipids. J Lipid Res 7:574-576

Marshall DJ, Pechenik JA, Keough MJ (2003) Larval activity levels and delayed metamorphosis affect post-larval performance in the colonial ascidian Diplosoma listerianum. Mar Ecol Prog Ser 246:153-162

Miller BA, Emlet RB (1999) Development of newly metamorphosed juvenile sea urchins (Strongylocentrotus franciscanus and $S$. purpuratus): morphology, the effects of temperature and larval food ration, and a method for determining age. J Exp Mar Biol Ecol 235:67-90

Miller KM, Carefoot TH (1989) The role of spatial and size refuges in the interaction between juvenile barnacles and grazing limpets. J Exp Mar Biol Ecol 134:157-174

Miron G, Boudreau B, Bourget E (1999) Intertidal barnacle distribution: a case study using multiple working hypotheses. Mar Ecol Prog Ser 189:205-219

Olivier F, Tremblay R, Bourget E, Ritschoff D (2000) Barnacle settlement: field experiments on the influence of larval supply, tidal level, biofilm quality and age on Balanus amphitrite cyprids. Mar Ecol Prog Ser 199:185-204

Parsons TR, Maita Y, Lalli CM (1984) A manual of chemical and biological methods for seawater analysis. Pergamon Press, Oxford

Pechenik JA (1990) Delayed metamorphosis by larvae of benthic marine invertebrates: Does it occur? Is there a price to pay? Ophelia 32:63-94

Pechenik JA (1999) On the advantages and disadvantages of larval stages in benthic marine invertebrate life cycles. Mar Ecol Prog Ser 177:269-297

Pechenik JA (2006) Larval experience and latent effectsmetamorphosis is not a new beginning. Integr Comp Biol 46:323-333

Pechenik JA, Rittschof D, Schmidt AR (1993) Influence of delayed metamorphosis on survival and growth of juvenile barnacles Balanus amphitrite. Mar Biol 115:287-294

Pechenik JA, Berard R, Daniels D, Gleason TR, Champlin D 
(2001) Influence of lowered salinity and elevated cadmium on the survival and metamorphosis of trochophores in Capitella sp. I. Invertebr Biol 120:142-148

Phillips NE (2002) Effects of nutrition-mediated larval condition on juvenile performance in a marine mussel. Ecology 83:2562-2574

Qiu JW, Qian PY (1999) Tolerance of the barnacle Balanus amphitrite amphitrite to salinity and temperature stress: effects of previous experience. Mar Ecol Prog Ser 188: 123-132

Raimondi PT (1990) Patterns, mechanisms, consequences of variability in settlement and recruitment of an intertidal barnacle. Ecol Monogr 60:283-310

Rainbow PS, Walker G (1977) The functional morphology and development of the alimentary tract of juvenile barnacles (Cirripedia: Thoracica). Mar Biol 42:337-349

Rittschof D, Clare AS, Gerhart DJ, Mary A, Bonaventura J (1992) Barnacle in vitro assays for biologically active substances: toxicity and settlement inhibition assays using mass cultured Balanus amphitrite Darwin. Biofouling 6: $115-122$

Roberts RD, Lapworth C (2001) Effects of delayed metamorphosis on larval competence, and post-larval survival and growth, in the abalone Haliotis iris Gmelin. J Exp Mar Biol Ecol 258:1-13

Sanford E, Menge BA (2001) Spatial and temporal variation in barnacle growth in a coastal upwelling system. Mar Ecol Prog Ser 209:143-157

Satuito CG, Shimizu K, Natoyama K, Yamazaki M, Fusetani N (1996) Age-related settlement success by cyprids of the barnacle Balanus amphitrite, with special reference to consumption of cyprid storage protein. Mar Biol 127:125-130

Editorial responsibility: Howard Browman (Associate Editorin-Chief), Storebø, Norway
Shriver AC, Carmichael RH, Valiela I (2002) Growth, condition, reproductive potential, and mortality of bay scallops, Argopecten irradians, in response to eutrophic-driven changes in food resources. J Exp Mar Biol Ecol 279:21-40 Thiyagarajan V, Harder T, Qian PY (2003a) Effects of TAG/DNA ratio and age of cyprid on post-metamorphic growth and survival in the barnacle Balanus amphitrite. J Mar Biol Assoc UK 83:83-88

Thiyagarajan V, Harder T, Qiu JW, Qian PY (2003b) Energy content at metamorphosis and growth rate of the early juvenile barnacle Balanus amphitrite. Mar Biol 143:543-554

Thiyagarajan V, Hung OS, Chiu JMY, Wu RSS, Qian PY (2005) Growth and survival of juvenile barnacle Balanus amphitrite: interactive effects of cyprid energy reserve and habitat. Mar Ecol Prog Ser 299:229-237

Underwood AJ, Keough MJ (2001) Supply-side ecology: the nature and consequences of variations in recruitment of intertidal organisms. In: Burtness MD, Gaines SD, Hay ME (eds) Marine community ecology. Sinauer Associates, Sunderland, MA, p 183-200

Wendt DE (1996) Effect of larval swimming duration on success of metamorphosis and size of the ancestrular lophophore in Bugula neritina (Bryozoa). Biol Bull (Woods Hole) 191:224-233

Wendt DE, Johnson CH (2006) Using latent effects to determine the ecological importance of dissolved organic matter to marine invertebrates. Integr Comp Biol 46:634-642

Wolcott DL, Devries MC (1994) Offshore megalopae of Callinectes sapidus: depth of collection, molt stage and response to estuarine cues. Mar Ecol Prog Ser 109:157-163

Zar JH (1999) Biostatistical analysis, 4th edn. Prentice Hall, Englewood Cliffs, NJ

Submitted: November 28, 2006; Accepted: February 16, 2007 Proofs received from author(s): July 16, 2007 